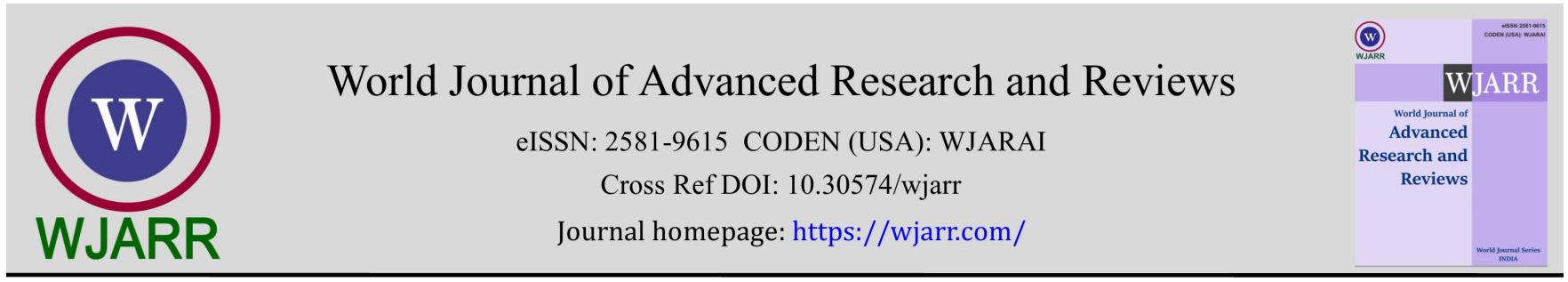

(RESEARCH ARTicle)

Check for updates

\title{
Level of knowledge regarding COVID-19 health protocols in the tourism sector in Taro village before and after counseling
}

\author{
Nofita Fachryandini ${ }^{1}$, Shabrina Nur Imanina ${ }^{1}$, Ayurveda Zaynabila Heriqbaldi ${ }^{1}$ and Widati Fatmaningrum ${ }^{2, *}$ \\ ${ }^{1}$ Medical Program, Faculty of Medicine, Universitas Airlangga, Surabaya, Indonesia. \\ 2 Department of Public Health, Faculty of Medicine, Universitas Airlangga, Surabaya, Indonesia.
}

World Journal of Advanced Research and Reviews, 2022, 13(01), 086-091

Publication history: Received on 29 November 2021; revised on 01 January 2022; accepted on 03 January 2022

Article DOI: https://doi.org/10.30574/wjarr.2022.13.1.0762

\begin{abstract}
Introduction: Taro village has a higher risk of gathering the people since it is one of the most popular tourism sectors in Bali hence increasing the potential to spread coronavirus disease 2019 (COVID-19). The level of knowledge plays an important role in determining whether the society is ready to implement the health protocols or not. This community service aims to evaluate the level of knowledge regarding COVID-19 health protocols in the tourism sector in the Taro village.
\end{abstract}

Method: This research was conducted using a quasi-experimental one-group pretest-posttest design in Taro village, Bali. Respondents filled out the questionnaire before and after counseling. The questionnaire consisted of 10 items of knowledge. The participants were Taro's residents who met inclusion and exclusion criteria. A total of 31 respondents were taken. The data were tested for normality with the Kolmogorov-Smirnov test and analyzed with paired T-test using the IBM SPSS statistics version 25. Significance was determined at a $5 \%$ level (P-value $\leq 0.05$ ).

Results: A total of 31 valid filled-questionnaires were collected. In general, Taro's residents' knowledge regarding COVID-19 health protocol in the tourism sector was sufficient, but some topics are still insufficient. The mean score before counseling was 79,03 $\pm 1,340$ while the mean score after counseling was $86,13 \pm 1,366$. There was a significant difference $(p<0,05)$ on level of knowledge $(p=0,000)$ before and after counseling.

Conclusion: There was a significant difference in the level of knowledge of Taro village's residents toward COVID-19 health protocols in the tourism sector before and after counseling.

Keywords: COVID-19; Knowledge; Protocols; Tourism

\section{Introduction}

Coronavirus disease 2019 (COVID19) is defined as a disease caused by a new type of coronavirus, that now called Severe Acute Respiratory Syndrome Coronavirus 2 (SARSCoV2; formerly known as 2019nCoV). COVID19 is a new respiratory infection that was first detected in Wuhan, Hubei Province, China in December 2019 [1] . COVID19 has spread widely and rapidly from Wuhan to other parts of the world, threatening the lives of many people [2] . In late January 2020, the World Health Organization (WHO) announced a public health emergency of international concern and called on all countries to work together to prevent its rapid spread. Subsequently, the WHO declared COVID19 as a "global pandemic. To date, more than 190 million positive cases of COVID-19 have been confirmed worldwide and at least 4 million people have died from COVID-19 [3,4].

\footnotetext{
${ }^{*}$ Corresponding author: Widati Fatmaningrum

Departement of Public Health, Faculty of Medicine, Universitas Airlangga, Surabaya, Indonesia.

Copyright $(2022$ Author(s) retain the copyright of this article. This article is published under the terms of the Creative Commons Attribution Liscense 4.0.
} 
The first two cases in Indonesia were confirmed in March 2020 and spread quickly across the country [3,4] . As of 20th July 2021, Indonesia has confirmed more than 2,9 million positive cases with more than 76 thousands death [5]. Therefore, the government has made many efforts in response to the COVID19 pandemic, including national budget policies, health emergency documents, and large-scale social restrictions [6]. Since the medical interventions available for treatment are limited, most countries have adopted various forms of non-pharmaceutical intervention (NPI), including lockdown (home isolation, voluntary/mandatory isolation), maintenance of social distance (vulnerable groups or the entire population), closure of schools/universities and non-essential businesses/workplaces, cancellation or postponement of events (i.e. large conferences and trade shows, concerts and festivals, political debates and elections, sports seasons and summer Olympics) and prohibit gatherings of more than a certain number of people are considered necessary to slow down the spread of COVID-19 as rapid person-to-person transmission has occurred [7,8]

Restrictions on international, regional, and local travel immediately affected the national economy, including the tourism system, namely international travel, domestic travel, day trips and air travel, cruises, public transport, accommodation, cafes and restaurants, conferences, festivals, conferences, etc. The announcement of the implementation of travel bans by the government affect $90 \%$ of tourist destinations and leisure businesses. The actual impact of the COVID19 pandemic on the tourism industry has become apparent [9] . The tourism sector has been a highly vulnerable sector to numerous environmental, political, socio-economic risks. The tourism sector is used to, and has become resilient in bouncing back from various crises and outbreaks [10]. Bali's tourism industry, as one of the most popular tourist destinations in the world, is also affected by this epidemic. Furthermore, this ongoing crisis may have a major impact on the tourism industry, especially small and medium-sized enterprises (SMEs) in tourist destinations, which are highly dependent on tourists as the main consumers [11] . Approximately 32.5 million workers were indirectly affected, including SMEs, money changers, souvenir shops, dancers, musicians, artists in tourist areas, hotel and restaurant suppliers, shopping malls, and retail workers. By the end of 2020, as many as 15 million jobs may be lost [12].

Public places and facilities especially in the tourism sector are areas where people carry out activities of social life and meet their needs. The risks of the movement of people and the gathering of people in the tourism area have great potential for the spread of COVID-19. To keep the wheels of the economy rolling, it is necessary to mitigate the impact of the COVID-19 pandemic, especially in public places and facilities. The community must change their lifestyle through a new order and habitual adaptation (new normal) so that they can live efficiently and avoid the spread of COVID-19. Adhering to the principles of a cleaner and healthier lifestyle is the key to slowing the spread of COVID-19 in the community $[13,14]$ states that social coherence between regulations and preparedness to tackle the disease was influenced by knowledge, attitude, and practice (KAP). In this community service and research, the level of knowledge is important to measure how well the residents understand the COVID-19 health protocols in the tourism sector.

\section{Material and methods}

This research used a quasi-experimental design with one group pretest-posttest design. The community service was conducted at Taro Village, Gianyar Province, Bali on $10^{\text {th }}$ July 2021. The community service participants were Taro's residents who met inclusion and exclusion criteria. The inclusion criteria for this community service was residents aged 15-65 years old. While the exclusion criteria for this community service were those who did not attend the counseling and could not read and/or write. A total of 31 respondents were taken. Respondents filled out the pre-test questionnaire before the counseling then filled out the post-test questionnaire after the counseling. The questionnaire consisted of demographic characteristics and 10 items of knowledge. The questionnaire given has been tested for validity and reliability. The independent variable of this community service was counseling about COVID-19 health protocols in the tourism sector. The dependents variable of this community service was the level of knowledge regarding the COVID-19 health protocols in the tourism sector. The data used are primary data obtained from the questionnaire. The data were tested for normality with the Kolmogorov-Smirnov test and analyzed with paired T-test using the IBM SPSS statistics version 25. Significance was determined at a $5 \%$ level ( $P$-value $\leq 0.05$ ).

\section{Results}

\subsection{Demographic Characteristics}

A total of 31 respondents was included in this community service. Table 1 shows the demographic characteristics of the community service respondents. As shown in Table 1, all the respondents were females. The majority of the sample $(41,93 \%)$ were between the ages of 17 and 25, followed by 35,48\% are 26-35 years old, 16,14\% are 46-55 years old, and $6,4 \%$ are $17-25$ years old. 
Table 1 Characteristics of Respondents by Gender and Age

\begin{tabular}{|l|c|c|}
\hline Characteristic & N (Total=31) & Percentage (\%) \\
\hline Gender \\
\hline Female & 31 & 100 \\
\hline Male & 0 & 0 \\
\hline Age & 2 & 6,45 \\
\hline $17-25$ & 11 & 35,48 \\
\hline $26-35$ & 13 & 41,93 \\
\hline $36-45$ & 5 & 16,14 \\
\hline $46-55$ & & \\
\hline
\end{tabular}

\subsection{Level of Knowledge Before and After Counseling}

The results showed that before attending the counseling, the highest pre-test score was 90 and the lowest score was 60 . Table 2 shows the level of knowledge before and after counseling. The mean pre-test score was 79,03 $\pm 1,340$. A total of 6 respondents $(19,36 \%)$ had pre-test scores below the average and 25 respondents $(80,64 \%)$ had pretest scores above the average. After attending the counseling, the highest post-test score was 100 and the lowest score was 70 . The average post-test score was $86,13 \pm 1,366$. Only 1 respondent $(3,23 \%)$ had post-test scores below the average and 30 respondents $(96,77 \%)$ had post-test scores above the average, representing an acceptable level of knowledge on COVID19 health protocols in the tourism sector. The knowledge score before and after counseling obtained a normal data distribution, so the paired T-test was used. The probability value obtained is $p=0,000$, so there is a significant difference $(\mathrm{p}<0,05)$ in the average level of knowledge before and after counseling.

Table 2 Level of Knowledge Before and After Counseling

\begin{tabular}{|l|c|c|c|c|c|}
\hline Knowledge Score & N & Mean \pm SD & Min & Max & P \\
\cline { 1 - 5 } Pre-test score & 31 & $79.03 \pm 1.340$ & 60 & 90 & \multirow{2}{*}{0.000} \\
\cline { 1 - 4 } Post-test score & 31 & $86,13 \pm 1,366$ & 70 & 100 & \\
\hline \multicolumn{6}{|c|}{ SD=Standard Deviation, min=minimum, max=maximum } \\
*Paired T-test
\end{tabular}

In Table 3, we can see that all respondents were aware that the tourism management was obligated to provide a place for sanitation in the form of hand sanitizer or a place for washing hands (100\%) and they were required to keep applying the health protocols even after getting COVID-19 vaccine (100\%). However, there was noticeable confusion among the respondents when it came to the obligation of tourism workers in implementing the health protocols because only $12,91 \%$ of the respondents answered correctly.

Table 3 Response to the Questionnaire on COVID-19 Knowledge about Health Protocols in Tourism Sector

\begin{tabular}{|c|l|l|l|l|l|}
\hline \multirow{2}{*}{ No. } & \multirow{2}{*}{ Questions } & \multicolumn{2}{|c|}{ Pre-test } & \multicolumn{2}{l|}{ Post-test } \\
\cline { 3 - 6 } & & Correct & Incorrect & Correct & Incorrect \\
\hline $\mathbf{1}$ & $\begin{array}{l}\text { Person obligated to carry out health } \\
\text { protocols in the tourism sector }\end{array}$ & $27(87.09 \%)$ & $4(12.91 \%)$ & $26(83.87 \%)$ & $5(16.13 \%)$ \\
\hline $\mathbf{2}$ & The latest variant of CoVID-19 & $24(77.41 \%)$ & $7(22.59 \%)$ & $31(100 \%)$ & $0(0 \%)$ \\
\hline $\mathbf{3}$ & Individual health protection & $28(90.32 \%)$ & $3(9.68 \%)$ & $31(100 \%)$ & $0(0 \%)$ \\
\hline $\mathbf{4}$ & $\begin{array}{l}\text { The main role in preventing the spread of } \\
\text { CoviD-19 }\end{array}$ & $29(93.54 \%)$ & $2(6.46 \%)$ & $31(100 \%)$ & $0(0 \%)$ \\
\hline
\end{tabular}


World Journal of Advanced Research and Reviews, 2022, 13(01), 086-091

\begin{tabular}{|c|l|l|l|l|l|}
\hline $\mathbf{5}$ & $\begin{array}{l}\text { The obligation of tourism management in } \\
\text { implementing the health protocols }\end{array}$ & $31(100 \%)$ & $0(0 \%)$ & $30(96.77 \%)$ & $1(3.23 \%)$ \\
\hline $\mathbf{6}$ & Things to do after getting CoviD-19 vaccine & $31(100 \%)$ & $0(0 \%)$ & $31(100 \%)$ & $0(0 \%)$ \\
\hline $\mathbf{7}$ & $\begin{array}{l}\text { Things to do if there is a crowd as a tourism } \\
\text { worker }\end{array}$ & $30(96.77 \%)$ & $1(3.23 \%)$ & $31(100 \%)$ & $0(0 \%)$ \\
\hline $\mathbf{8}$ & $\begin{array}{l}\text { The obligation of tourism workers in } \\
\text { implementing the health protocols }\end{array}$ & $4(12.91 \%)$ & $27(87.09 \%)$ & $9(29.03 \%)$ & $22(70.97 \%)$ \\
\hline $\mathbf{9}$ & $\begin{array}{l}\text { Enforcement of health protocols by tourism } \\
\text { worker }\end{array}$ & $28(90.32 \%)$ & $3(9.68 \%)$ & $25(80.64 \%)$ & $6(19.36 \%)$ \\
\hline $\mathbf{1 0}$ & Benefit of getting CoVID-19 vaccine & $17(54.83 \%)$ & $14(45.17 \%)$ & $18(58.06 \%)$ & $13(41.94 \%)$ \\
\hline
\end{tabular}

\section{Discussion}

Due to its rapid transmission, COVID-19 is an aggressive virus. Primary prevention measures are implemented by changing personal hygiene behaviors and restricting physical and social contact between people. In addition, since this disease is new, it is important to avoid misinformation that may lead to wrong preventive measures in society. To date, there has been limited published data on population knowledge regarding COVID-19 health protocols in the tourism sector, especially in Indonesia. This community service helps to fill the knowledge gaps in Indonesian people's knowledge about COVID-19 health protocols in the tourism sector since Indonesia especially Bali is one of the most favorite destinations for tourism.

All respondents of this community service came from females $(100 \%)$. This may be related to the tendency of men to be more apathetic than females in participating in a survey. Previous study showed the same results, in which females mainly responded to the survey as $73 \%$ and $88,5 \%[15,16]$. Most of the respondents aged between 36 and 45 years old and categorized as late adulthood or early elderly [17] . WHO stated that the elderly are at the highest risk of contracting the virus, with more than $95 \%$ of related deaths [4]. Various health conditions, especially chronic disease and decreased immunity are expected to significantly increase the vulnerability of the elderly to COVID-19. A large-scale campaign about COVID-19 health protocols encouraged the elderly to learn more about COVID-19 [18] .

Based on respondents' results, it shows that most respondents had a sufficient level of knowledge regarding COVID-19 health protocols in the tourism sector. The mean score of the knowledge level on the pretest is $79,03 \pm 1,340$ and $80,64 \%$ of respondents had a pretest score above the average. These results are in line with research conducted in China that reported the majority of the respondents (90\%) had a satisfactory score on the COVID-19 knowledge level [19] . Similarly, a previous research report showed that Nepalese residents were aware of COVID-19 [20] . A study in Egypt also stated similar results that showed respondents generally had good knowledge [21] . However, another study conducted in Bangladesh showed that the knowledge of the participants is insufficient and suggests that health authorities should provide up-to-date knowledge to strengthen adequate prevention of COVID-19 outbreak [22]. Some studies have assessed the knowledge of respondents, but their studies include healthcare workers rather than community residents $[23,24]$.

After the counseling about COVID-19 health protocols in the tourism sector, there is an increase in respondent's average scores. The average post-test score is $86,13 \pm 1,366$. This average score increases when compared to the average pretest score. Based on the test carried out, there are significant differences at the level of knowledge $(p<0,05)$ after getting counseling regarding COVID-19 health protocols in the tourism sector, indicating that it is necessary to increase knowledge level with counseling.

In the recognition process, a person recognizes objects in 2 ways, through observation and paying attention and through reason. The process of cognition through reason takes place in 3 stages, namely the formation of understanding, the formation of opinions, and the formation of decision-making. After someone observes and pays attention, there will be an image that stays in memory or called response. This response will affect the learning process. The respondents began to recognize the COVID-19 health protocols in the tourism sector after receiving the counseling. After the introduction process, the respondents get new learning that allows respondents to be able to answer questions better so that there is an increase in the level of knowledge [25] . 
This community service has certain limitations, therefore the interpretations of the results should be conducted with care. The first limitation is the instrument used in this community service. The questionnaire is self-designed because there is no gold standard questionnaire for measuring the level of knowledge regarding COVID-19 health protocols in the tourism sector. In addition, possible factors contributing to knowledge such as educational level, occupations, and health literacy were not measured in this community service. These would have been a useful addition in understanding the knowledge of COVID-19 health protocols in the tourism sector in Indonesia [26,27] . Additionally, the participants of this community service were over-representative of females. Therefore, there are limitations to the representativeness of this research.

\section{Conclusion}

Based on the results and discussions that have been stated, it can be concluded that there is a significant difference in the level of knowledge regarding COVID-19 health protocols in the tourism sector of Taro Village's residents before and after counseling. The level of knowledge after counseling is better than before counseling.

\section{Compliance with ethical standards}

\section{Acknowledgments}

The authors would like to thank Taro Village's stake holders and residents for the participation as respondents in this study. We also would like to thank Faculty of Medicine, Universitas Airlangga, Surabaya, Indonesia for facilitating and supporting this study.

\section{Disclosure of conflict of interest}

The authors declare that there is no conflict of interest that would affect the findings of this study.

\section{Statement of informed consent}

Informed consent was obtained from all participants included in this study.

\section{References}

[1] Wu F, Zhao S, Yu B, Chen YM, Wang W, Song ZG, et al. A new coronavirus associated with human respiratory disease in China. Nature. 2020;579(7798):265-9.

[2] Wang D, Hu B, Hu C, Zhu F, Liu X, Zhang J, et al. Clinical Characteristics of 138 Hospitalized Patients with 2019 Novel Coronavirus-Infected Pneumonia in Wuhan, China. JAMA - J Am Med Assoc. 2020;323(11):1061-9.

[3] WHO Indonesia. Coronavirus Disease 2019 (COVID-19) situation report [Internet]. WHO. 2020. Available from: https://www.who.int/indonesia/news/novel-coronavirus/situation-reports

[4] WHO. WHO Coronavirus (COVID-19) [Internet]. World Health Organization. 2021. Available from: https://covid19.who.int/

[5] Satuan Tugas Penanganan COVID-19. Peta Sebaran COVID-19 [Internet]. 2021. Available from: https://covid19.go.id/peta-sebaran-covid19

[6] Djalante R, Lassa J, Setiamarga D, Sudjatma A, Indrawan M. Review and analysis of current responses to COVID19 in Indonesia : Period of January to March 2020 누. Progess Disaster Sci. 2020;6:1-9.

[7] Anderson RM, Heesterbeek H, Klinkenberg D, Hollingsworth TD. How will country-based mitigation measures influence the course of the COVID-19 epidemic? Lancet. 2020;395(10228):931-4.

[8] Cao J, Tu W, Cheng W, Yu L. Clinical Features and Short-term Outcomes of 102 Patients with Corona Virus Disease 2019 in Wuhan, China 2 . Institute of Radiation Medicine, China Academy of Medical Science \& Peking Union Medical College , Tianjin , China 3 . Department of Infectious. Oxford Univ Press. 2019;(238):4-21.

[9] Gössling S, Scott D, Hall CM. Pandemics, tourism and global change: a rapid assessment of COVID-19. J Sustain Tour [Internet]. 2020;0(0):1-20. Available from: https://doi.org/10.1080/09669582.2020.1758708

[10] Novelli M, Gussing L, Jones A, Ritchie BW. 'No Ebola...still doomed'- The Ebola-induced tourism crisis. Ann Tour Res J. 2018;70(January):76-87. 
[11] Kemenparekraf. KAJIAN DAMPAK SEKTOR PARIWISATA TERHADAP PEREKONOMIAN INDONESIA [Internet]. Kementerian Pariwisata dan Ekonomi Kreatif / Badan Pariwisata dan Ekonomi Kreatif Republik Indonesia. 2019. Available from: https://www.kemenparekraf.go.id/post/kajian-dampak-sektor-pariwisata-terhadapperekonomian-indonesia

[12] M. Rifki Fadilah. STUDI ANALISIS DAMPAK COVID-19 KE SEKTOR PARIWISATA INDONESIA SERTA RESPONS KEBIJAKAN. Indones Inst Cent Public Policy Res. 2020;1-33.

[13] Azlan AA, Hamzah MR, Sern TJ, Ayub SH, Mohamad E. Public knowledge, attitudes and practices towards COVID19: A cross-sectional study in Malaysia. PLoS One [Internet]. 2020;15(5):1-15. Available from: http://dx.doi.org/10.1371/journal.pone.0233668

[14] Kementrian Kesehatan Republik Indonesia. KEPUTUSAN MENTERI KESEHATAN REPUBLIK INDONESIA NOMOR HK.01.07/MENKES/382/2020. 2020.

[15] Sulistyawati S, Rokhmayanti R, Aji B, Wijayanti SPM, Hastuti SKW, Sukesi TW, et al. Knowledge, attitudes, practices and information needs during the covid-19 pandemic in indonesia. Risk Manag Healthc Policy. 2021;14:163-75.

[16] Khaled A, Siddiqua A, Makki S. The knowledge and attitude of the community from the aseer region, saudi arabia, toward covid-19 and their precautionary measures against the disease. Risk Manag Healthc Policy. 2020;13:1825-34.

[17] Al Amin M, Juniati D. Klasifikasi Kelompok Umur Manusia Berdasarkan Analisis Dimensi. J Ilm Mat. 2017;2(6):110 .

[18] Begley S. What explains Covid-19's lethality for the elderly? Scientists look to 'twilight' of the immune system. STAT NEWS [Internet]. 2020; Available from: https://www.statnews.com/2020/03/30/what-explainscoronavirus-lethality-for-elderly/

[19] Zhong BL, Luo W, Li HM, Zhang QQ, Liu XG, Li WT, et al. Knowledge, attitudes, and practices towards COVID-19 among chinese residents during the rapid rise period of the COVID-19 outbreak: A quick online cross-sectional survey. Int J Biol Sci. 2020;16(10):1745-52.

[20] Hussain A, Garima T, Singh BM, Ram R, Tripti RP. Knowledge, attitudes, and practices towards COVID-19 among Nepalese Residents: A quick online cross-sectional survey. Asian J Med Sci. 2020;11(3):6-11.

[21] Abdelhafiz AS, Mohammed Z, Ibrahim ME, Ziady HH, Alorabi M, Ayyad M, et al. Knowledge, Perceptions, and Attitude of Egyptians Towards the Novel Coronavirus Disease (COVID-19). J Community Health [Internet]. 2020;45(5):881-90. Available from: https://doi.org/10.1007/s10900-020-00827-7

[22] Rahman A, Sathi NJ. Knowledge, attitude, and preventive practices toward COVID-19 among Bangladeshi internet users. Electron J Gen Med. 2020;17(5).

[23] Zhang M, Zhou M, Tang F, Wang Y, Nie H, Zhang L, et al. Knowledge, attitude, and practice regarding COVID-19 among healthcare workers in Henan, China. J Hosp Infect. 2020;105:183-7.

[24] Huynh G, Nguyen T, Tran V, Vo K, Vo V, Pham L. Knowledge and attitude toward COVID-19 among healthcare workers at District 2 Hospital, Ho Chi Minh City. Asian Pac J Trop Med. 2020;13(6):260-5.

[25] Notoatmodjo S. Promosi Kesehatan dan Perilaku Kesehatan. Rineka Cipta; 2012.

[26] Hamzah MR, Mohamad E, Abdullah MY b. Influence of health literacy on health information seeking behavior among students in public university. J Komun Malaysian J Commun [Internet]. 2016;32(2):405-24. Available from:

https://www.researchgate.net/publication/318241690_Influence_of_health_literacy_on_health_information_se eking_behavior_among_students_in_public_university

[27] Mohamad EMW, Kaundan MK, Hamzah MR, Azlan AA, Ayub SH, Tham JS, et al. Establishing the HLS-M-Q18 short version of the European health literacy survey questionnaire for the Malaysian context. BMC Public Health. 2020;20(1):1-7. 